Original Contribution

\title{
EFFICACY OF ULTRA-LOW VOLUME DISINFECTION WITH HYDROGEN PEROXIDE VAPOUR IN A POULTRY HATCHERY
}

\author{
G. Zhelev ${ }^{1 *}$, Il. Lazarov ${ }^{2}$ \\ ${ }^{1}$ Department of Veterinary Microbiology, Infectious and Parasitic Diseases, Faculty of Veterinary \\ Medicine, Trakia University, Stara Zagora, Bulgaria \\ ${ }^{2} \mathrm{PhD}$ student, Faculty of Veterinary Medicine, Trakia University, Stara Zagora, Bulgaria
}

\begin{abstract}
Good hygiene in the hatcheries is one of the most important factors for normal hatching, low embryonic mortality and healthy chickens. The best disinfectant in these sites should combine high antimicrobial efficiency, lack of damages on the eggs and embryos, and has to be harmless for the staff and the environment. One of the few disinfectants which meets all these conditions is hydrogen peroxide. This study presents data on the effectiveness of disinfection with hydrogen peroxide vapour in a poultry hatchery. Nocolyse One Shot disinfectant (Oxy Pharm, France), containing 12\% hydrogen peroxide and silver ions was used, which was applied by Nocospray (an ultra-low volume application device, Oxy Pharm, France) in a dose of $5 \mathrm{~mL}$ per $1 \mathrm{~m}^{3}$. The results obtained show high efficiency of the disinfection treatments. The achieved microbial reduction in the hatchers was in the range from $95.51 \%$ $\left(1.35 \log _{10}\right)$ for the floor to $99.89 \%\left(2.95 \log _{10}\right)$ for the air. The reduction of microbial contamination during the processing of hatching eggs was in the rate of $99.75 \%\left(2.6 \log _{10}\right)$. The high efficiency of the treatments, the low toxicity and ecological safety of the hydrogen peroxide and the ease way of its application are the reasons to extend the implementation of the method in hatchery hygiene practices.
\end{abstract}

Key words: poultry, hatchery, hatching eggs, hydrogen peroxide vapour, ULV disinfection

\section{INTRODUCTION}

In healthy parent flocks, the egg surface and the egg contents are sterile at the time of egg laying. Once they have been laid, such eggs suffer secondary contamination on contact with the nest or the transport belts, or as a result of their storage, transportation or handling (1). Apart from the contaminated eggs, other sources of microbial contamination in the hatchery are the staff, equipment, the air flow and especially the residual microbial contamination from the previous batch of chickens (1-2).

Found themselves in the hatchery, microorganisms have optimal conditions for growth-suitable temperature, humidity and nutrients. It has been established that under such

\footnotetext{
*Correspondence to: Dr. Georgi Zhelev, e-mail: zhelev_vet@abv.bg,tel.: +35942699614, $+359896976443$
}

conditions, only within 24 hours one bacterial cell could multiply to $4.7 \times 10^{24}$ cells (1).

Hence, within a very short time, microbial contamination in the hatchery may increase drastically. This threatens seriously the embyo health and provokes the spread of contagious diseases. That is why ensuring a good hygiene in the hatchery is one of the most important factors for the trouble-free egg hatching, low embryo mortality rate and production of healthy chickens (2-3).

The disinfection programme should be able to efficiently reduce microbial contamination and maintain low levels of some key microorganisms with significant impact for hatcheries such as Salmonella spp., Pseudomonas spp., Proteus spp., E. coli, Staphylococcus spp., Streptococcus spp. and Aspergillus spp. $(1,4)$. 
It is known that not all of the disinfectants are able to inactivate all types of microorganisms. For example, quaternary ammonium compounds which are widely used, are not able to inactivate bacterial spores and non-enveloped viruses, and some bacteria such as Pseudomonas spp. and Enterococcus spp. exhibit very high resistance (5).

Other disinfectants possess a very high antimicrobial activity and a broad spectrum but they quite easily damage the equipment (alkalies, acids, hypochlorites) and/or release toxic gases (aldehydes, chlorine-releasing compounds, phenols). Some of them (formaldehyde) are known carcinogens. Their use poses a very serious risk for the health of the hatchery workers (5-8).

The best disinfectant in hatcheries should combine high antimicrobial efficiency, lack of damages on the equipment, eggs and embryos, and has to be harmless for the staff and the environment. One of the few disinfectants which meet all these conditions are oxygen releasing compounds and their representative is hydrogen peroxide $(5,7-8)$.

Nocolyse One Shot disinfectant (Oxy Pharm, France) is a bio- disinfectant for air and surfaces disinfection, which contains $12 \%$ hydrogen peroxide and silver ions. The method of its application is by ultra-low volume (ULV) manner by using an ULV device (Nocospray, Oxy Pharm, France), which emits a mist of the disinfectant with particle size around $5 \mu \mathrm{m}(9)$.

This disinfection method stands out with a number of advantages such as: 1) broad spectrum: it has bactericidal, virucidal, fungicidal and sporicidal activity; 2) it is harmless to the staff: lack of any toxic or allergenic substances; 3) it is harmless to the environment: it is decomposed to non-toxic products; 4) it is harmless to the equipment: it is suitable for all types of surfaces including electronic ones, without corroding or oxidizing effect; 5) it is easy to apply: automated systems; 6) very small quantity of the product are needed $1-5 \mathrm{~mL}$ per $\mathrm{m}^{3}$ (9-11). Its excellent efficacy has been established by a number of scientific studies in laboratory conditions $(12,13)$, in an industrial bread factory (14) and even for disinfection of diving suits (15).

The significant advantages of this method mentioned above make it especially suitable for use also in the poultry farming. This gave us a reason to deepen our studies in its disinfection efficacy in the real hatchery practice and under the ambient conditions specific for these type of sites.

\section{MATERIAL AND METHODS}

ZHELEV G., et al.

The studies were carried out in two poultry hatcheries located in South Bulgaria.

In hatchery 1, disinfection of a hatching cabinet was carried out. After vacating the cabinet from the newly-hatched chickens, the cabinet was mechanically cleaned and washed using a high-pressure water jet. After drying of all surfaces, ultra-low volume disinfection (ULV) was carried out with Nocolyse One Shot disinfectant (Oxy Pharm, France), applied by Nocospray (an ULV device) in dose of 5 $\mathrm{mL} / \mathrm{m}^{3}$ and 120 minutes exposure time.

The efficacy of the disinfection was determined by microbiological testing by estimating the percentage of the microbial reduction achieved expressed by the difference between the number of microorganisms on the surfaces tested (floor, wall, equipment) and air before and after the disinfection. With the same purpose, we also estimated the $\log 10$ reduction of the microbial contamination using the formula below (16): $\log _{10}$ reduction = $\log _{10}$ pre-disinfection bacterial count $-\log _{10}$ after- disinfection bacterial count.

a) The samples of the surfaces were taken by microbiological swab method (17). A sterile moistened cotton swab was rubbed in a surface of $25 \mathrm{~cm}^{2}$ by using sterile cardboard templates. The samples were put in tubes, containing $10 \mathrm{~mL}$ sterile distilled water and refrigerated during transportation to the laboratory. Sample homogenization and content extraction was performed by shaking in a vortex mixer for 3 minutes, after which the tampons were removed from the tubes. Ten-fold dilutions (from $10^{-1}$ to $10^{-7}$ ) were prepared in sterile distilled water. For the quantification of the total bacterial count, aliquots of $0.1 \mathrm{~mL}$ from the primary dilution and the corresponding decimal dilutions were sowed in Triptone Soya Agar w/Lecithin and Polysorbate 80 (HiMedia, India). The samples were incubated at $37^{\circ} \mathrm{C}$ and aerobic atmosphere for $48 \mathrm{~h}$. The grown colonies were counted twice - on the 24th and 48th hour of the incubation, and final result was presented as the highest colony amount. The counting was performed by using a digital colony counter (Colony counter LA660, HiMedia, India). The amount of microorganisms per 1 $\mathrm{cm}^{2}$ of the control surfaces was calculated depending on the number of grown colonies on the agar and the corresponding rate of dilution. For every control surface, 6 cotton swab samples were examined and the average results were presented. 
b) The air samples were obtained by a passive sedimentation method. Petri dishes, containing Triptone Soya Agar w/Lecithin and Polysorbate 80 (HiMedia, India), with a diameter of $8.5 \mathrm{~cm}$ were used. The plates were arranged at different heights in the hatchery cabinet. They were opened for a certain period of time (from 2 to $10 \mathrm{~min}$.) pursuant to the expected microbial contamination. The samples were incubated at $37^{\circ} \mathrm{C}$ and aerobic atmosphere for $48 \mathrm{~h}$. The grown colonies were counted twice-on the 24th and 48th hour of the incubation, and the highest number of bacteria cells was taken as a final result. Depending on the number of grown colonies on the agar and the exposure of the Petri dishes, a total bacterial count of $1 \mathrm{~m}^{3}$ was determined (18). Six Petri dishes were placed on different levels and the average results were taken.

In hatchery 2, disinfection of the hatching eggs was carried out. After placement of the egg batch in the fumigation chamber, ULV disinfection with Nocolyse One Shot disinfectant, applied by
ZHELEV G., et al.

Nocospray in dose of $5 \mathrm{~mL} / \mathrm{m}^{3}$ and 60 minutes exposure time took place.

The efficacy of the disinfection was determined by estimating the achieved reduction of microbial contamination on the egg surface (CFU per egg). With this purpose, using sterile latex gloves, the eggs were placed in a sterile polyethylene bag containing $10 \mathrm{~mL}$ sterile distilled water and they were vigorously rubbed. From rinsed fluids tenfold dilutions were prepared by the method described in paragraph a) to determine the total bacterial count on the egg surface before and after disinfection.

The statistical data processing was performed using GraphPad software. Comparison of the results before and after disinfection was performed by unpaired t-test. The differences were considered as statistically significant when $\mathrm{P}$ value was less than $0.05(\mathrm{P}<0.05)$.

\section{RESULTS}

The results of the microbiological examinations of the samples are presented in Table 1 and 2.

Table 1. Efficacy of ULV disinfection of hatching cabinet with Nocolyse One Shot disinfectant (Oxy Pharm, France) in dose of $5 \mathrm{~mL} / \mathrm{m}^{3}$ and 120 minutes exposure time.

\begin{tabular}{|c|c|c|c|c|c|c|}
\hline \multirow{3}{*}{ ڤั̃ } & \multirow{3}{*}{ 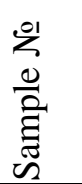 } & \multirow{2}{*}{\multicolumn{2}{|c|}{$\begin{array}{c}\text { After washing } \\
\text { /Initial contamination/ }\end{array}$}} & \multicolumn{3}{|c|}{ After disinfection } \\
\hline & & & & \multicolumn{2}{|c|}{ Microbial contamination } & \multirow{2}{*}{$\begin{array}{l}\text { Microbial } \\
\text { reduction }\end{array}$} \\
\hline & & $\mathrm{CFU} / \mathrm{cm}^{2 / 3}$ & Average & $\mathrm{CFU} / \mathrm{cm}^{2 / 3}$ & Average & \\
\hline$\frac{\grave{0}}{\check{\partial}}$ & $\begin{array}{l}1 \\
2 \\
3 \\
4 \\
5 \\
6\end{array}$ & $\begin{array}{l}2.51 \times 10^{3} \\
1.47 \times 10^{3} \\
0.39 \times 10^{3} \\
1.75 \times 10^{3} \\
1.26 \times 10^{3} \\
0.99 \times 10^{3}\end{array}$ & 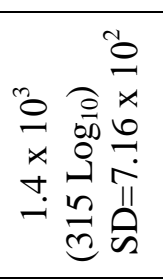 & $\begin{array}{c}8.21 \times 10^{1} \\
0 \\
6.46 \times 10^{1} \\
6.87 \times 10^{1} \\
6.23 \times 10^{1} \\
9.88 \times 10^{1}\end{array}$ & 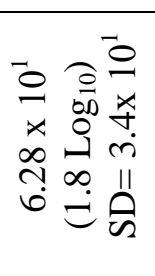 & 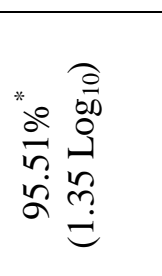 \\
\hline $\bar{\sigma}$ & $\begin{array}{l}1 \\
2 \\
3 \\
4 \\
5 \\
6\end{array}$ & $\begin{array}{c}7.52 \times 10^{2} \\
12.54 \times 10^{2} \\
8.15 \times 10^{2} \\
4.33 \times 10^{2} \\
7.17 \times 10^{2} \\
0.98 \times 10^{2}\end{array}$ & 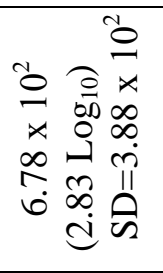 & $\begin{array}{c}0 \\
0 \\
0 \\
4.56 \times 10^{1} \\
0.98 \times 10^{1} \\
2.23 \times 10^{1}\end{array}$ & 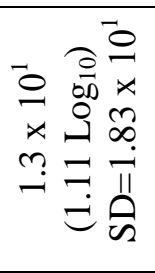 & 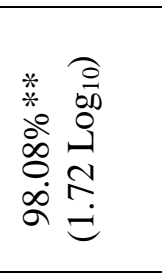 \\
\hline 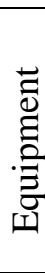 & $\begin{array}{l}1 \\
2 \\
3 \\
4 \\
5 \\
6\end{array}$ & $\begin{array}{l}18.44 \times 10^{2} \\
9.32 \times 10^{2} \\
4.16 \times 10^{2} \\
8.88 \times 10^{2} \\
8.54 \times 10^{2} \\
6.14 \times 10^{2}\end{array}$ & 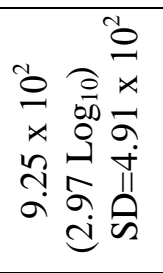 & $\begin{array}{c}0 \\
0 \\
4.44 \times 10^{1} \\
4.22 \times 10^{1} \\
3.08 \times 10^{1} \\
2.27 \times 10^{1}\end{array}$ & 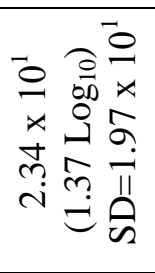 & 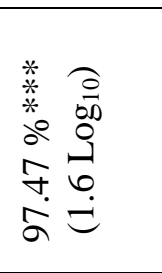 \\
\hline 娄 & $\begin{array}{l}1 \\
2 \\
3 \\
4 \\
5 \\
6\end{array}$ & $\begin{array}{c}7.48 \times 10^{4} \\
6.4 \times 10^{4} \\
6.41 \times 10^{4} \\
8.07 \times 10^{4} \\
7.49 \times 10^{4} \\
7.61 \times 10^{4}\end{array}$ & 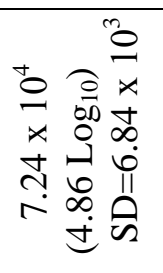 & $\begin{array}{c}8.81 \times 10^{1} \\
7.93 \times 10^{1} \\
7.05 \times 10^{1} \\
7.93 \times 10^{1} \\
6.17 \times 10^{1} \\
10.58 \times 10^{1}\end{array}$ & 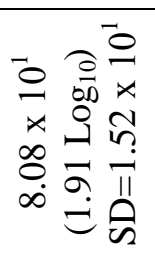 & 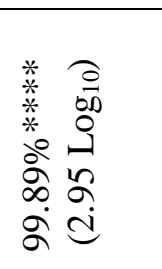 \\
\hline
\end{tabular}

Legend: SD - Standard Deviation; * Indicate statistical significance of the differences $(\mathrm{p}<0.05):{ }^{*} \mathrm{p}=0.0011 ;{ }^{* *} \mathrm{p}$ $=0.0019 ;{ }^{* * *} \mathrm{p}=0.0012 ;{ }^{* * * *} \mathrm{p}=0.0001$. 
ZHELEV G., et al.

Table 2. Efficacy of ULV disinfection of hatching eggs with Nocolyse One Shot disinfectant (Oxy Pharm, France) in dose of $5 \mathrm{~mL} / \mathrm{m}^{3}$ and 60 minutes exposure time.

\begin{tabular}{|c|c|c|c|c|c|c|}
\hline \multirow{2}{*}{$\begin{array}{l}\frac{0}{2} \\
\frac{0}{\pi} \\
\bar{\Xi} \\
\tilde{\Xi} \\
\tilde{n}\end{array}$} & \multicolumn{2}{|c|}{$\begin{array}{l}\text { Microbial contamination } \\
\text { before disinfection }\end{array}$} & \multirow{2}{*}{ 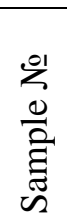 } & \multicolumn{2}{|c|}{$\begin{array}{l}\text { Microbial contamination } \\
\text { after disinfection }\end{array}$} & \multirow[t]{2}{*}{$\begin{array}{l}\text { Microbial } \\
\text { reduction }\end{array}$} \\
\hline & CFU/Egg & Average & & CFU/Egg & Average & \\
\hline 1 & $1.44 \times 10^{6}$ & \multirow{12}{*}{ 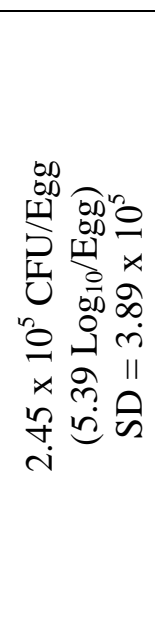 } & 13 & $3.2 \times 10^{2}$ & \multirow{12}{*}{ 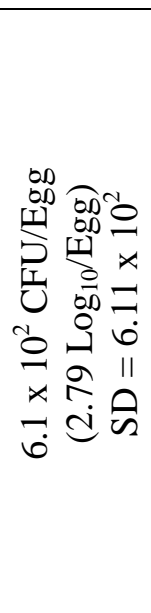 } & \multirow{12}{*}{ 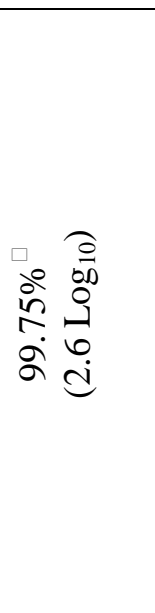 } \\
\hline 2 & $3.0 \times 10^{4}$ & & 14 & $1.4 \times 10^{3}$ & & \\
\hline 3 & $8.0 \times 10^{4}$ & & 15 & $9.42 \times 10^{1}$ & & \\
\hline 4 & $2.4 \times 10^{5}$ & & 16 & $4.5 \times 10^{2}$ & & \\
\hline 5 & $1.0 \times 10^{5}$ & & 17 & $3.2 \times 10^{1}$ & & \\
\hline 6 & $5.0 \times 10^{4}$ & & 18 & $8.87 \times 10^{2}$ & & \\
\hline 7 & $1.0 \times 10^{5}$ & & 19 & $4.55 \times 10^{2}$ & & \\
\hline 8 & $1.22 \times 10^{5}$ & & 20 & $3.66 \times 10^{2}$ & & \\
\hline 9 & $3.2 \times 10^{5}$ & & 21 & $8.7 \times 10^{1}$ & & \\
\hline 10 & $3.0 \times 10^{5}$ & & 22 & $6.61 \times 10^{2}$ & & \\
\hline 11 & $2.09 \times 10^{4}$ & & 23 & $4.44 \times 10^{2}$ & & \\
\hline 12 & $1.4 \times 10^{5}$ & & 24 & $2.13 \times 10^{3}$ & & \\
\hline
\end{tabular}

Legend: SD - Standard Deviation; ${ }^{\square}$ Indicate statistical significance of the differences $(\mathrm{p}<0.05): \mathrm{p}=0.0405$.

\section{DISCUSSION}

The high antimicrobial activity and the broad spectrum of the hydrogene peroxide vapour have been proven by a number of scientific studies (19). Boyce at al., (20) and Barbut at al., (21) have found that hydrogen peroxide vapour has good sporicidal activity and leads to complete inactivation of Clostridium difficile spores regardless of strain and/or surface. Berrie at al., (22) and Bentley at al., (23) have found that it has good virucidal activity even in case of highly environment resistant viruses such as adenoviruses and feline caliciviruses. Hydrogen peroxide vapor inactivates even the most resistant microorganisms: prions (24). This is why this method is recommended for decontamination of contaminated sites in case of infectious outbreaks or nosocomial infections (25-26). Fu at al. (27) conclude that this is a safe, fast and effective method for decontamination. According to Klapes \& Vesley (28) hydrogen peroxide vapour is a real alternative of the fumigation with ethylene oxide or formaldehyde vapours, without their adverse side effects. Opposed to ethylene oxide and formaldehyde, hydrogen peroxide vapour has very low toxicity, it is not cancerogenic and it has no residual smell in the disinfected premises.

Ayubi \& Karadzhov (29) performed aerosol disinfection in egg hatcheries using iodophor disinfectant. They achieved $93.9 \%$ average reduction of the microbial contamination of the air and $88.6 \%$ of the different control surfaces (floor, wall, equipment). Carrying out ULV disinfections of the hatching eggs and hatching cabinets with Nocolyse One Shot disinfectant, we have achieved a better disinfection efficacy of the treated surfaces. For all control zones a high statistically significant reduction $\left(>95 \%,>1.3 \quad \log _{10}\right)$ of the microbial contamination has been established. The highest percentage of the microbial reduction achieved is that of the air in the hatching cabinet $99.89 \%\left(2.95 \log _{10}\right)$ and the surface of the fumigated eggs $99.75 \% \quad\left(2.6 \quad \log _{10}\right)$. Sheldon \& Brake (3) also established a high level of efficacy of the disinfection of hatching eggs with hydrogen peroxide which is comparable to that achieved by fumigation with formaldehyde. Authors proved that treatment of the eggs with hydrogen peroxide does not damage the egg shell and the embryo, but even significantly increases their hatching rate and the quality of the newly hatched chickens.

With regard to ULV disinfection carried out using Nocolyse disinfectant, Orlando at al., (12) established a significant difference in the efficacy of the method in terms of the horizontal and vertical surfaces. They observed significantly better efficacy on the vertical surfaces. In comparison to this, at the time of our studies we have not registered any statistically significant difference in the method efficacy between the vertical and horizontal surfaces With this method of disinfection (ULV) the disinfectant is emitted in the form of very small particles (approx. $5 \mu \mathrm{m}$ ) 
which evenly fill up the entire disinfected volume and ensure even contact with all surfaces disinfected. That is why we believe that if there are any differences in the disinfection efficacy; those are rather attributable to the impact of the different types of materials (metal, paint or plastic) as they possess different properties and characteristics, directly affecting the disinfection efficacy, and not that much to their orientation.

\section{CONCLUSIONS}

Based on the results obtained, as well as the summary of the published scientific data, it can be concluded that:

1. ULV disinfection of hatching eggs and hatching cabinets with hydrogen peroxide vapour (Nocolyse One Shot disinfectant, applied by Nocospray device (Oxy Pharm, France) in a dose of $5 \mathrm{~mL}$ per $1 \mathrm{~m}^{3}$ ) features a high level of disinfection efficacy.

2.The established high level of efficacy, easy application and low toxicity, make fumigation with Nocolyse One Shot disinfectant (Oxy Pharm, France) a suitable disinfection method in the hatching practice and a real alternative of the fumigation with the significantly more toxic formaldehyde.

\section{REFERENCES}

1. Thermote, Ir. L., Effective hygiene within the hatchery. International Hatchery Practice, 20 (5): 18-21, 2006.

2. Samberg, Y., Meroz, M., Application of disinfectants in poultry hatcheries. Scientific and Technical Review of the Office International des Epizooties, 14: 365-380, 1995.

3. Sheldon, B. W., Brake, J., Hydrogen peroxide as an alternative hatching egg disinfectant. Poult Sci, 70 (5): 1092-8, 1991.

4. Magwood, S.E ., Marr, H., Studies in hatchery sanitation 2. A simplified method for assessing bacterial populations on surfaces within hatcheries. Poult Sci, 43:1558-1566, 1964.

5. Karadzhov, S., Ivanov, Y., Nedelchev, N., Kesyakova, S., Disinfection, Disinsection and Deratization in Foot and Mouth Disease. Milena Print, Sofia (BG), 2004.

6. IARC (International Agency for Research on Cancer), Formaldehyde, 2-Butoxyethanol and 1-tert-Butoxypropan-2-ol. IARC Monographs on the Evaluation of Carcinogenic Risks to Humans, 88: 1-287, 2006. PMID: 17366697.

7. Ivanov, Y., Nedelchev, N., Karadjov, St., Kesiakova, S, Filipov, Ch., Pepovich, R., General Epizootology and Preventive Medicine. Sofia, 2013.

8. Russell, Hugo and Ayliffe's Principles and Practice of Disinfection, Preservation and
ZHELEV G., et al.

Sterilization, 5th edition, Wiley-Blackwell, 2013.

9. OxyPharm, Technical data sheet - Nocolyse One Shot, 2017.

https://www.oxypharm.net/wpcontent/uploads/2018/06/Technical-DataSheet-NOCOLYSE-ONE-SHOT_vB-1.pdf (07 June 2019, date last accessed).

10. OxyPharm, Brochure, 2019 http://www.dutchsmartsolutions.nl/sites/defa ult/files/bestanden/ specificaties_0.pdf (07 June 2019, date last accessed).

11. Dorobanţu, D., Arsene, C., Lupu, E., Radu, A., Oltean, G., Chelmus,, R., Disinfection air and surfaces: contemporary fine by forming a $5 \mathrm{~mm}$ without wetting on the basis of hydrogen peroxide - nocolyse generated by nebulizer Nocospray. Veterinary Drug, 9 (2): $60-63,2015$.

12. Orlando, P., Cristina, M. L., Dallera, M., Ottria, G., Vitale, A., Badolati, G., Surface disinfection: evaluation of the efficacy of a nebulization system spraying hydrogen peroxide. Journal of Preventive Medicine and Hygiene, 49: 116-119, 2008.

13. Sala, A., Pianetta, C., Bracco, S., Luzzaro, F., Evaluation of Nocosystem efficacy in disinfecting surfaces by air. Microbiologia medica, 25 (4): 265 - 267, 2010.

14. Giannone, V., Pitino, I., Pecorino, B., Todaro, A., Spina, A., Lauro, M. R., Tomaselli, F., Restuccia, C., Effects of innovative and conventional sanitizing treatments on thereduction of Saccharomycopsis fibuligera defects on industrial durum wheat bread. Int $J$ Food Microbiol, 235: 71-76, 2016.

15. Dąbrowiecki, Z., Dąbrowiecka, M., Olszański, R., Siermontowski, P., Decontamination of a diving suit. Pol. Hyperb. Res., 4 (57): 45-54, 2016.

16. Ekizoglu, M.T., Özalp, M., Sultan, N., Gur, D., An investigation of the bactericidal effect of certain antiseptics and disinfectants on some hospital isolates of gram-negative bacteria. Infect Control Hosp Epidemiol., 24 (3): 225-227, 2003.

17. Baldock, J. D., Microbiological monitoring of the food plant: methods to assess bacterial contamination on surfaces. J Milk Food Technol, 37 (7): 361-368, 1974. doi:10.4315/0022-2747-37.7.361

18. Stryjakowska-Sekulska, M., PiotraszewskaPajak, A., Szyszka, A., Nowicki, M., Filipiak, M., Microbiological quality of indoor air in university rooms. $P O L J$ ENVIRON STUD, 16 (4): 623-632, 2007.

19. McDonnell, G., The Use of Hydrogen Peroxide for Disinfection and Sterilization Applications. PATAI'S Chemistry of 
Functional Groups: 1-34, 2014. doi:10.1002/9780470682531.pat0885

20. Boyce, J.M., Havill, N.L., Otter, J.A., McDonald, L. C., Adams, N.M., Thompson, A., Wiggs, L., Noble-Wang, J., Impact of hydrogen peroxide vapor room biodecontamination on environmental contamination and nosocomial transmission of Clostridium difficile. Infect Control Hosp Epidemiol., 29: 723-729, 2008.

21. Barbut, F., Yezli, S., Otter, J., Activity in vitro of hydrogen peroxide vapour against Clostridium difficile spores. J Hosp Infect. , 80: 85-87, 2012.

22. Berrie, E., Andrews, L., Yezli, S., Otter, J.A., Hydrogen peroxide vapour (HPV) inactivation of adenovirus. Letters in Applied Microbiology, 52 (5): 555-558, 2011.

23. Bentley, K., Dove, B.K., Parks, S.R., Walker, J.T., Bennett, A.M., Hydrogen peroxide vapour decontamination of surfaces artificially contaminated with norovirus surrogate feline calicivirus. J Hosp Infect., 80:116-21, 2012.

24. Fichet, G., Antloga, K., Comoy, E., Deslys, J. P., McDonnell, G., Prion inactivation using a new gaseous hydrogen peroxide sterilization process. J Hosp Infect., 67: 27886, 2007.
ZHELEV G., et al.

25. French, G. L., Otter, J. A., Shannon, K. P., Adams, N. M. T., Parks, M. J., Watling, D, Tacking contamination of the hospital environment by methicillin-resistant Staphylococcus aureus (MRSA): a comparison between conventional terminal cleaning and hydrogen peroxide vapour decontamination. J Hosp Infect., 57: 31-37, 2004.

26. Bates, C.J., Pearse, R., Use of hydrogen peroxide vapour for environmental control during a Serratia outbreak in a neonatal intensive care unit. J Hosp Infect., 61: 364366, 2005.

27. Fu, T.Y., Gent, P., Kumar, V., Efficacy, efficiency and safety aspects of hydrogen peroxide vapour and aerosolized hydrogen peroxide room disinfection systems. J Hosp Infect. , 80: 199-205, 2012.

28. Klapes, N. A., Vesley, D., Vapor-phase hydrogen peroxide as a surface decontaminant and sterilant. $J$ Appl Environ Microbiol., 56 (2): 503-506, 1990.

29. Ayubi, N. M., Karadzhov, S., Disinfection of a hall for sexing and sorting of chickens by means of Desinfect B aerosol. Veterinarna Sbirka, 102: 22-24 (BG), 1994. 